\title{
AN INNOVATIVE APPROACH TO THE INTEGRATED MANAGEMENT SYSTEM DEVELOPMENT: SIMPRO-IMS WEB BASED ENVIRONMENT
}

\author{
KRISTINA ZGODAVOVA, PETER BOBER
}

\section{INTRODUCTION}

The purpose of integration and implementation of management systems by integrating standards and documents is in the achievement of their synergistic action in the organization. Standards are living documents, which reflect progress in science, research, technology and systems. In some regulated areas, it is entirely impossible to do without standards. They must be agreed and followed. In other areas, they are useful especially for those who do not know how to do something, but also serve well to those who know how to do it, but want to make sure that they are doing it correctly, or even better than prescribed by the standard. At the same time, standards promote and unify communication. In particular, the ISO (International Organization for Standardization) standards positively contribute to the running of the world we live in (ISO 26000 Social Responsibility, 2010). They ensure vital features such as quality, ecology, safety, reliability, compatibility, interoperability, efficiency and effectiveness. They facilitate trade, spreading of knowledge and sharing of technological progress and good management and leadership practices (ISO, 2010).

Management standards serve as an example (model) for setting up the organization at its establishment and operation. This model than includes features on which experts in the area arrived to a consensus according to how knowledge and international state of the art evolved. At present (by title and abstract), there is 161 ISO management systems standards, 22 of them refers to quality management system according to ISO 9001 and 47 standards refers to PDCA cycle. Globally, the state in the certification of management systems according to ISO Survey of certifications from the year 2010 is as follows: there is 1,109,905 ISO 9001 certified, 250,972 ISO 14001 certified, 43,946 ISO/TS 16949, and 15,625 ISO 27001 certified organizations according (ISO, 2011).

Many organizations have adopted or are adopting formal management system standards and/or specifications such as ISO 9001, ISO 14001, ISO/IEC27001, ISO 22000, ISO/IEC 20000, OHSAS 18001 and now also ISO 50001. The first internationally recognized specification of requirements for the integration of management systems PAS 99:2006 (British Standards Institution, 2006) was prepared according to six common characteristics: 
- Policy

- Planning

- Implementation and operation

- Performance assessment

- Improvement

- Management review

The paper deals with the integration and implementation of selected management standards into the organization through Integrated Management System RolePlay Simulation (SIMPRO-IMS).

Former SIMPRO-Q education environment has been developed and tested during a period of 15 years in several industrial organizations as well as service organizations such as Higher Education Institution (HEI) and Healthcare Organization (HCO). The newest version SIMPRO-IMS has recently been developed to support a need of integration of management systems and information archiving. With the last development, SIMPRO-IMS web based environment, processes of five ISO systems are integrated for parallel development, implementation, auditing, maintaining and leading. SIMPRO-IMS provides management with the apparatus necessary to realize a systematic and verifiable approach to the creation and control of IMS documentation.

\section{METHODOLOGY}

The research methodology is based on ISO standards integration and innovation management system application.

Many of the requirements in standards/specifications are common for the aforementioned standards and these can be practically accommodated under one generic management system. It follows that the reduction in duplication by combining two or more systems in this way has the potential to reduce the overall size of the management system significantly and improve system efficiency and effectiveness (British Standards Institution, 2006).

Integration according to PAS 99:2006 should be planned and implemented in a structured way so that they apply the Plan-Do-Check-Act (PDCA) improvement cycle.

Quality Management Role-Play Simulation (SIMPRO-Q) has been used since 1996 in its initial version developed at the Technical University of Kosice (TUKE) (QM-RPS, 1996 - 2010). It was necessary to create new processes in the database of SIMPRO-Q according common requirements of quality, environmental management and healthcare and safety management for the new role-play SIMPRO-IMS. Furthermore, the structure of the database should allow simple adding of requirements from another standards e.g. from ISO/IEC27001, 
ISO 22000, ISO/IEC 20000, ISO 50001 in order to integrate these management standards. A simplified matrix of relationships between managerial processes and elements of standards encoded in SIMPRO-IMS database and the PDCA cycle is in Table 1.

Table 1 - A simplified matrix of relationships between managerial processes and different elements of standards ISO 9001, ISO 14001 OHSAS 18001

\begin{tabular}{|c|c|c|c|c|c|}
\hline Processes & $\begin{array}{l}\text { PAS } \\
99\end{array}$ & $\begin{array}{l}\text { ISO } \\
9001\end{array}$ & $\begin{array}{l}\text { ISO } \\
14001\end{array}$ & $\begin{array}{l}\text { OHSAS } \\
18001\end{array}$ & PDCA \\
\hline Management system policy creation and maintenance & 4.2 & $5.1,5.3$ & 4.2 & 4.2 & \multirow[t]{7}{*}{$\mathbf{P}$} \\
\hline Planning & 4.3 & & 4.3 & 4.3 & \\
\hline $\begin{array}{l}\text { Identification and evaluation of aspects, impacts and } \\
\text { risks }\end{array}$ & 4.3 .1 & $\begin{array}{l}5.2, \\
5.4 .2, \\
7.2 .1, \\
7.2 .2\end{array}$ & 4.3 .1 & 4.3 .1 & \\
\hline Identification of legal and other requirements & 4.3 .2 & $\begin{array}{l}5.3(\mathrm{~b}) \\
7.2 .1(\mathrm{c})\end{array}$ & 4.3 .2 & 4.3 .2 & \\
\hline Contingency planning & 4.3 .3 & 8.3 & 4.4 .7 & 4.4 .7 & \\
\hline Objectives creation and actualization & 4.3 .4 & 5.4 .1 & 4.3 .3 & 4.3 .3 & \\
\hline $\begin{array}{l}\text { Organizational structure, roles, responsibilities and } \\
\text { authorities establishment and maintenance }\end{array}$ & 4.3 .5 & 5.5 & 4.4.1 & 4.4 .1 & \\
\hline Implementation and operation & 4.4 & & & & \multirow[t]{5}{*}{ D } \\
\hline Operational control & 4.4 .1 & 7 & 4.4 .6 & 4.4 .6 & \\
\hline Management of resources & 4.4 .2 & 6 & $\begin{array}{l}4.4 .1 \\
4.4 .2\end{array}$ & $\begin{array}{l}4.4 .1 \\
4.4 .2\end{array}$ & \\
\hline Documentation requirements specification & 4.4 .3 & 4.2 & $\begin{array}{l}4.4 .4, \\
4.4 .5 \\
4.5 .4\end{array}$ & $\begin{array}{l}4.4 .4 \\
4.4 .5 \\
4.5 .3\end{array}$ & \\
\hline Communication & 4.4 .4 & $\begin{array}{l}5.5 .3 \text {, } \\
7.2 .3 \text {, } \\
5.3(\mathrm{~d}), \\
5.5 .1\end{array}$ & 4.4 .3 & 4.4 .3 & \\
\hline Performance assessment & 4.5 & & & & \multirow[t]{5}{*}{$\mathbf{C}$} \\
\hline Monitoring and measurement & 4.5 .1 & 8.1 & 4.5 .1 & 4.5 .1 & \\
\hline Evaluation of compliance & 4.5 .2 & 8.2 .4 & 4.5 .2 & 4.5 .1 & \\
\hline Internal auditing & 4.5 .3 & 8.2 .2 & 4.5 .5 & 4.5 .4 & \\
\hline Handling of nonconformities & 4.5 .4 & 8.3 & 4.5 .3 & 4.5 .2 & \\
\hline Improvement & $\begin{array}{l}4.6 \\
4.6 .1\end{array}$ & 8.5 .1 & 4.5 .3 & 4.5 .2 & \multirow[t]{5}{*}{$\mathbf{A}$} \\
\hline Corrective, preventive and improvement action & 4.6 .2 & $\begin{array}{l}8.5 .2 \\
8.5 .3\end{array}$ & 4.5 .3 & 4.5 .2 & \\
\hline Management Review & $\begin{array}{l}4.7 \\
4.7 .1\end{array}$ & 5.6 .1 & 4.6 & 4.6 & \\
\hline Input creation & 4.7 .2 & 5.6 .2 & & & \\
\hline Output creation & 4.7 .3 & 5.6 .3 & & & \\
\hline
\end{tabular}

An ISO based integrated management system (IMS) can be used as the foundation for an innovation management system by using definition according to (Dahlgaard-Park and Dahlgaard, 2010) and the integrated ISO requirements (Table 1) with a deeper level of thinking and application during the role-play. 
The key element in concerning to an innovative product and process solution according (Merrill, 2010) should be a methodology, which take us 'out of the box', engages people inside and outside the organization.

SIMPRO-IMS should take players out of the 'standards box' using creative thinking and finding innovative solutions especially in the process of corrective, preventive and improvement actions according to the PAS 99:2006, chapter 4.6.2.

\section{INTERPRETATION OF SIMPRO ROLE-PLAY SIMULATION}

Simulation as advisable and purposeful experimenting with a model has found its fixed place in many fields and disciplines, the overview of which can be found in e.g. (Cadotte and Bruce, 1996; Houshyar and Nuila, 1998). Besides simulations in dynamic socio-eco-technical systems, simulation could be used also for people training. In a simulated, floating environment, a person acquires new skills and learns how to react to new situations. Such training is cost-effective and experience can confirm its fruitfulness (Harrington, 1999). The further development of this idea is the utilization of human activities in a simulated environment for its modification and creation of a new and a better environment. As a result, there are two facts: (i) a new environment, and (ii) new skills of a person in this new environment. Overcoming the resistance against change should be equally included among new skills (Zgodavova, 2009). The resistance arises as a natural human reaction to change and often prevents the onset and exploitation of new methods and new tools (Reger, et al., 1994; Zgodavova, et al., 2001). The involvement of an individual in a particular situation leads to such modification of the environment that it reflects actual abilities of the participants. This is useful in the further application of the system thus created.

Francis and Byrne, 1999; Oberhofer, 1999 as cited in Mark Sutcliffe (1994) suggests "Many studies have claimed that simulations, games and role-play (SGRP), especially when group based, have contributed to a positive change in classroom dynamics. It has been suggested that they help break down barriers and stimulates a greater level of long-term interactivity between students players".

Sutcliffe (2011, p. 2) states that "Simulations become role-plays when the student is expected to act as they imagine appropriate to a given role. As games usually require tight rules, role-plays are likely to give more scope for the student to exercise their own interpretation of the role when the simulation is not constructed as a game".

From the theoretical point of view, role-play simulation belongs to the qualitative and quantitative (Q\&Q) simulation of the socio-eco-technical systems. The process of Q\&Q modelling and simulation development and practical utilization started in 1980s (Kuipers 1994; 2001). 
From the methodological point of view, role-play simulation has a character of abduction where a particular case is dealt with according to the rules applied and results achieved. In our terms, the rule is represented by descriptions of processes required by standards and creativity of players and the result is given or is supposed to be given by the improved activities pertaining to the organization management system. As far as abduction is concerned, likewise induction, it provides only probable results (Saunders and Cox, 1997; Freeman and Capper, 1999). SIMPRO-IMS differs from a usual scenario-driven play in the description of roles. Unlike in the latter description, in the former one it is known what to do only, not who and how should do it.

The position of SIMPRO-IMS within the frame of modelling, simulation and correcting of socio-eco-technical reality in an organisation with the purpose of fulfilling the IMS criteria is shown on the Figure. 1.

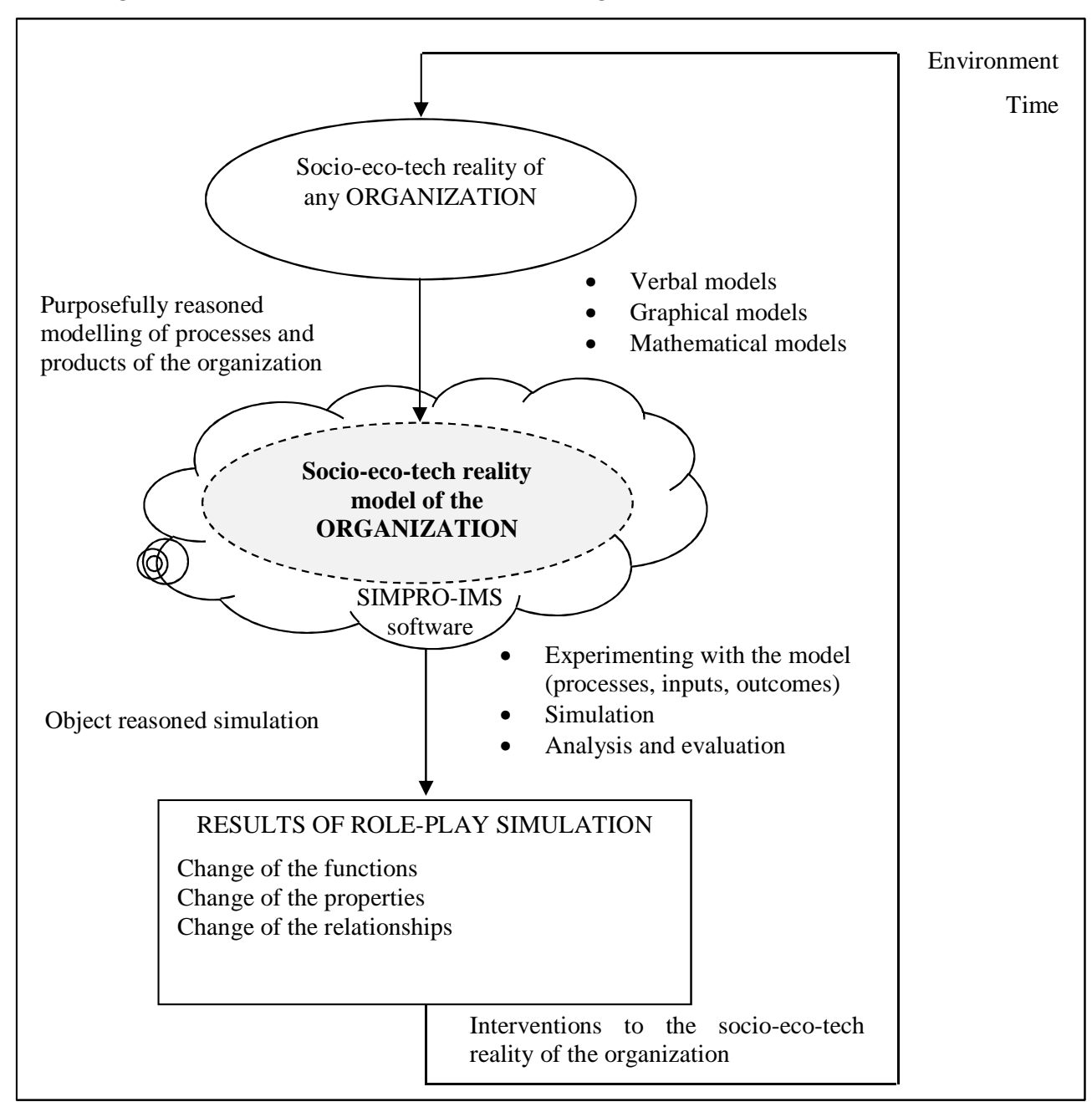

Figure 1 - Position of the SIMPRO-IMS within the frame of the modelling, simulation and correcting of socio-eco-technical reality in an organization 


\section{IMS ROLE-PLAY SIMULATION DESCRIPTION}

The mission of SIMPRO-IMS is the employment and development of player's creativity in the process of integration and implementation of the management system based on in advance accepted verbal model.

The nature of the role-play simulation is experimenting with pre-selected model of the management system in model organization, acceptance of system processes by players, creation of the basic documentation, and testing of its operation for good organization administration. Objectives of the role-play are:

- To present the organization with respect to its main features;

- To decide on an appropriate integration model of management systems;

- To define and to model processes of the IMS;

- To experiment with the main and supportive processes of the organization;

- To experiment with inputs and outputs of processes;

- To create the documentation of designed management system;

- Auditing of the created IMS;

- To test the management system functions and operation.

The essence of the role-play simulation of the integrated management system is the team experimentation of designated group of managers with the verbal models of in advance created processes (Table 1) of the IMS, and to achieve consensus on the distribution of the processes among the organization and its members and to achieve the functionality and ability to be certified. The functionality of the system is demonstrated by achieving the required performance indicators and stakeholder satisfaction.Elaboration of the required IMS documentation and records of the state of quality, environmental, health and safety at work and overall sustainability of the organization determine the certification of the system.

A consensus on the distribution of IMS processes can be reached by the argumentation the following four areas:

- the relation between the main processes, supportive processes and managerial processes;

- the content and form of documentation and records concerning the accepted processes of IMS;

- the cost covering the implementation of the accepted IMS processes;

- the competence to perform accepted processes in the rhythm of changes in the main processes of the organization. 
Verbal model of the IMS is developed in advance in compliance with the requirements of integration (Tab. 1), method of management and in accordance with specific organisational needs.

If necessary, the IMS verbal model can be complemented by mathematical, graphical, and other models. This may be relevant mainly in case of wider IMS information and communication technology support.

\subsection{IMS role-play simulation process}

SIMPRO-IMS process in its simplified form is demonstrated in Figure 2.

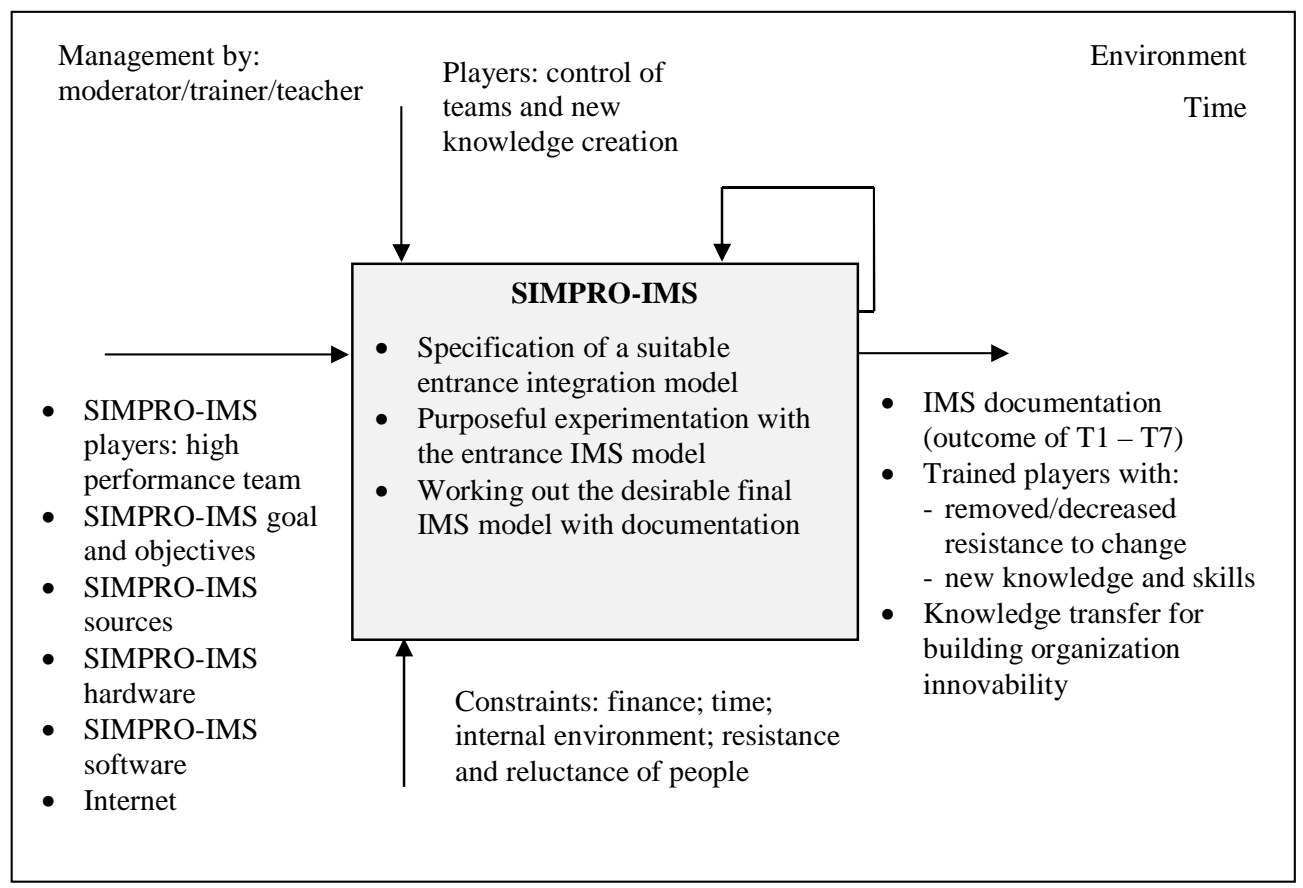

Figure 2 - Basic illustration of the SIMPRO-IMS process

Objectives of SIMPRO-IMS are ordered and arranged with respect to their complexity as following tasks (T):

T1: To be able to define and select an appropriate entrance integration model.

T2: To understand and be able to describe the IMS processes in accordance with the selected model.

T3: To understand and be able to solve outputs documentation of the IMS processes associated with the accepted managerial role in an organization.

T4: To acquire the knowledge according to T3 and; moreover, to be able to diagnose such knowledge, adjustments and improve the processes associated with the accepted managerial role in an organization. 
T5: To acquire the knowledge according to T4 and be able to apply such knowledge in the creation of IMS manual - in the matrix of managerial processes and their performers.

T6: To acquire the knowledge according to T5 and; moreover, to be able to apply a value analysis to the IMS of an organization.

T7: To acquire the knowledge according to T6 and; moreover, to have adequate expertise to participate in an internal IMS auditing in accordance with ISO 19011:2011 Guidelines for auditing management systems.

To meet the purpose of role-plays in respect to the SIMPRO-IMS, phases described in the Table 1 can be formulated as follows (Table 2):

Table 2 - SIMPRO-IMS phases and learning stages for building the organization innovability

\begin{tabular}{|c|c|c|}
\hline \multicolumn{2}{|c|}{ Stage } & SIMPRO-IMS Phase \\
\hline \multirow{7}{*}{ 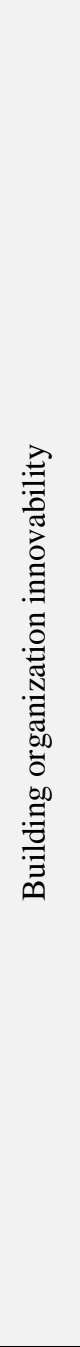 } & Learning & $\begin{array}{l}1^{\text {st }} \text { phase: Presentation of the organization } \\
\text { - Familiarization with the organization; (replication of the } \\
\text { organizational structure, the replication process, replication of } \\
\text { work management process); } \\
\text { - Finding the right places for the right people in the project; } \\
\text { - Acceptance of position in an organization. }\end{array}$ \\
\hline & \multirow[t]{2}{*}{$\begin{array}{l}\text { Knowledge } \\
\text { creation }\end{array}$} & $\begin{array}{l}2^{\text {nd }} \text { phase: Experimentation with the processes of the organization IMS } \\
\text { - Selection from processes randomly distributed between players; } \\
\text { - Acceptance of assigned processes; } \\
\text { - Taking responsibility for the processes. }\end{array}$ \\
\hline & & $\begin{array}{l}3^{\text {rd }} \text { phase: Experimenting with organization IMS process input /output } \\
\text { information (documents) } \\
\text { - Selecting from randomly distributed output documents; } \\
\text { - Acceptance from distributed output documents; } \\
\text { - Formulation of the comparative effective value. }\end{array}$ \\
\hline & \multirow[t]{3}{*}{$\begin{array}{l}\text { Knowledge } \\
\text { transfer }\end{array}$} & $\begin{array}{l}4^{\text {th }} \text { phase: Definition, modelling and simulation of main processes } \\
\text { - Main processes definition in the QPR Process Guide environment; } \\
\text { - Main processes modelling in the QPR Process Guide environment; } \\
\text { - Main processes simulation QPR Process Guide environment. }\end{array}$ \\
\hline & & $\begin{array}{l}5^{\text {th }} \text { phase: Preparation of IMS documentation } \\
\text { - Improved descriptions of managerial tasks; } \\
\text { - Defined and modelled processes of the organization IMS; } \\
\text { - Responsibility and competence matrices in the organization IMS. }\end{array}$ \\
\hline & & $\begin{aligned} 6^{\text {th }} & \text { phase: Internal auditing of IMS } \\
\text { - } & \text { Obtaining evidence of audit; } \\
\text { - } & \text { Evaluation of the audit evidence; } \\
\text { - } & \text { Audit findings and conclusions. }\end{aligned}$ \\
\hline & $\begin{array}{l}\text { Knowledge } \\
\text { verification }\end{array}$ & $\begin{array}{l}7^{\text {th }} \text { phase: Experimenting with the functioning of the project QMS } \\
\text { - Testing of the modelled situation in a project (falling behind } \\
\text { schedule, etc.); } \\
\text { - Analysis of reasons, evaluation of the definition of responsibilities; } \\
\text { - Improvements and preventive actions taken. }\end{array}$ \\
\hline
\end{tabular}




\subsection{SIMPRO-IMS software description}

SIMPRO software is developed in the PHP language and MySQL database is selected for data storage. Necessary entries for further role-play development are stored in testing version of relation database of Microsoft SQL Azure and the software will be tested in the private cloud of TUKE CRELABTE ${ }^{\odot}$ from the year 2012.

The database includes:

- The main situation types for the ISO managerial standards and integration models;

- Models of the main organization types (main characteristic features of the industrial organization, healthcare organization, education organization, service organization).

- The main situation types in product quality from the technological, material, production and service-provision points of view.

- IMS process description according to PAS 99:2006 (ISO 9001:2008; ISO 14001; BS OHSAS 18001:2007). Database is prepared also for role-play with following standards:

o ISO/IEC 27001:2005 Information technology - Security techniques Information security management systems - Requirements

o ISO 22000:2005 Food safety management systems - Requirements for any organization in the food chain

o ISO/IEC 20000-1:2011 Information technology - Service management - Part 1: Service management system requirements

o OHSAS 18001:2007 Occupational health and safety management systems - Requirements

o ISO 22301:2012 Societal security - Business continuity management systems - Requirements

o ISO 50001:2011 Energy management systems - Requirements with guidance for use

○ ISO 26000:2010 Guidance on social responsibility

- Link to the QPR SUITE 2012 software for process definition and modelling. Graphical models of main processes in the value chain and relevant activities or groups of activities have to be performed by particular players responsible for the process.

- Blank matrixes of IMS processes and players (owners) competence and responsibilities;

- Blank graphical template for the IMS manual, documentation and records;

- The main cases for testing adverse situations;

- The link between process owner and adverse situations. 
Moderator/teacher or trainer can moderate the role-play and create new tasks from different places accessing SIMPRO-IMS software from PC or diverse mobile devices. The findings and results from new role-plays are also stored in a database.

\section{CONCLUSION}

Based on our years of experience in applying role-play simulation:

- Players like to take part in the role-play simulation.

- Managers can acquire a more plastic picture about the significance, benefits, and particularly about the functioning of the IMS in an organization and consequently, quickly apply their knowledge in practical activities.

- On the basis of the overall activity and the level of solutions found, it is then possible to proceed with the individual evaluation and positioning of particular managers.

- Even after the implementation of the IMS, mastering the role-play simulation becomes an excellent tool for its further improvement, as it can be applied quickly and repeatedly and thus serving as a tool for the detection of the system response to any change.

- Building organization innovability using role-play simulation should be exploited as frequently as necessary or as agreed on by the owners, top executives and middle managers, but also by other people in an organization. Wise is the time to prepare for the need for innovating advance innovation.

- Positive results can be seen as early as after the first proper application of the IMS role-play simulation in the overall organization culture, but also in the reduction of costs, the process and product improvements, customer satisfaction, and in the total performance of an organization.

Development and progress in the methodology of SIMPRO-IMS web based environment is encoded in upgrading the SIMPRO database by processes of the environmental management, occupational health \& safety management, information security management, energy management, service management, business continuity management and social responsibility management into one cohesive system with a holistic set of documentation, policies, procedures and processes, and a preserving knowledge for learning, new knowledge creation and knowledge transfer for building organization innovability.

The research is limited by the complexity of a real system and possible empiric results verification. The results achieved are verified when people really overcome the resistance to change. This can be assessed thoughtfully only after some period of time. Another limitation is presented by measurability of real 
enhancement achieved in quality, safety and environmentality of production, and business continuity and social responsibility of an organization.

Paper is intended for all professionals who are concerned with the educational theory and/or methodology in the field of IMSs or their practical application.

\section{ACKNOWLEDGMENTS}

This work is supported by the Scientific Grant Agency of the Ministry of Education, Science, Research and Sport of the Slovak Republic, project KEGA 009-4/2011: Creative Laboratory Education at Technical Faculties “CRELABTE" (75\%).

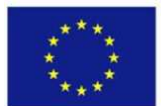

Európska únia

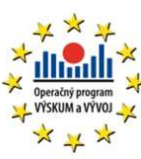

We support research activities in Slovakia / Project is cofinanced from EU funds. This paper was developed within the Project "Centrum excelentnosti integrovaného výskumu a využitia progresívnych materiálov a technológií v oblasti automobilovej elektroniky", ITMS 26220120055 (25\%).

\section{REFERENCES}

British Standards Institution (2006), PAS 99:2006 Specification of common management system requirements as a framework for integration, London: BSI Group, ISBN 0580490599.

Cadotte, E. R. and Bruce, H. J. (1996), Marketplace, The Ultimate in Business Competition, Knoxville College, University of Tennessee, USA.

Dahlgaard-Park, S. M. and Dahlgaard, J. J. (2010), “Organizational Learnability and Innovability: A system for assessing, diagnosing and Improving Innovations", International Journal of Quality and Service Sciences, (2), ISSUE 2, pp. 153-174, DOI: 10.1108/17566691011057339.

Freeman, M. A. and Capper, J. M. (1999), "Exploiting the web for Education: An Anonymous Asynchronous Role Simulation", Australian Journal of Educational Technology, 1999, 15(1), pp. 95-116.

Harrington, H. J. (1999), Simulation Modeling Methods, McGraw - Hill Companies, Inc., USA, ISBN 0-07-027136-4.

Houshyar, A. and Nuila, V. (1998), "Survey of Academia and Industry on Exploitation of Simulation", International Journal of Modeling and Simulation, Vol. 18, No. 1, pp. 45-53.

ISO (2010), Strategic Plan 2011-2015, [pdf] Available at:

http://www.iso.org/iso/iso_strategic_plan_2011-2015.pdf, Accessed 15 May, 2012

ISO (2011), The ISO Survey of certifications 2010, Edition: 18, ISBN 978-92-6710560-4. 
ISO 26000 Social Responsibility (2010), Discovering Social Responsibility, ISBN 978-92-67-10538-3, [pdf] Available at:

http://www.iso.org/iso/discovering_iso_26000.pdf, Accessed 30 May, 2012.

Kuipers, B. (1994), Qualitative Reasoning - Modelling and Simulation with Incomplete Knowledge, MIT Press, Cambridge, MA, USA.

Merrill, P. (2010), From ISO 9001 to an Innovation Management System, The ASQ World Conference on Quality St. Louis, MO, May 24-26, 2010, [pdf] Available at:

http://community.asq.org/app/documents/documenthandler.ashx?d=adfacae01515-468a-9376-0e6ea48feb41, Accessed 30 May, 2012

QM-RPS (1996 - 2011), Quality Management Role-Play Simmulation, [online] Available at: http://simpro-q.org/simpro/index_en.htm

Reger, R. K., Gustafson, L. T., Demaire, S. M. and Mullane, J. V. (1994), "Reframing the Organisation: Why Implementing Total Quality is Easier Said than Done", Academy of Management Review, 1994, Vol. 19, No. 3565 - 584.

Sauders, P. and Cox, B. (1997, The International Simulation and Gaming Yearbook, volume 5, Research Into Simulation in Education, Kogan Page, UK.

Sutcliffe, M. (2011), "Simulations, Games and Role-play", in: The Handbook for Economics Lecturers, Edited by $\operatorname{Dr}$ Peter Davies, [pdf] Available at: http://www.economicsnetwork.ac.uk/handbook/printable/games_v5.pdf, Accessed 15 May, 2012

Zgodavova, K. (2009), "Overcoming Resistance to Change Via Managerial RolePlay Simulation", Chapter 24 in DAAAM International Scientific Book 2009, pp. 223-232, B. Katalinic (Ed.), Published by DAAAM International, ISBN 978-3901509-69-8, ISSN 1726-9687, Vienna, Austria

DOI: $10.2507 /$ daaam.scibook.2009.24

Zgodavova, K., Kosc, P. and Kekale, T. (2001), "Learning Before Doing: Utilizing a Co-operative Role-Play for Quality Management in a Virtual Organisation", Journal for Workplace Learning 13 (3), pp. 113 - 118.

\section{ABOUT THE AUTHORS}

Kristina Zgodavova, prof. PhD., Technical University of Kosice, Faculty of Metallurgy, Department of Integrated Management, e-mail: kristina.zgodavova@tuke.sk

Peter Bober, PhD., Technical University of Kosice, Faculty of Electrical Engineering and Informatics, Department of Electrical Engineering and Mechatronics, e-mail: peter.bober@tuke.sk 